\title{
Article \\ Effect of Calcium Treatment on Inclusions in H08A Welding Rod Steel
}

\author{
Fangjie Lan ${ }^{1}$, Changling Zhuang ${ }^{1,2, *}$, Changrong $\mathrm{Li}^{1,2}$, Guangkai Yang ${ }^{1}$ and Hanjie Yao ${ }^{1}$ \\ 1 Metallurgy Department, College of Material and Metallurgy, Guizhou University, Guiyang 550025, China; \\ fangjielan@163.com (F.L.); crli@gzu.edu.cn (C.L.); 18085037568@163.com (G.Y.); \\ yhj1394542756@163.com (H.Y.) \\ 2 Key Laboratory of Metallurgical Engineering and Process Energy Saving of Guizhou Province, \\ College of Material and Metallurgy, Guizhou University, Guiyang 550025, China \\ * Correspondence: clzhuang@gzu.edu.cn
}

Citation: Lan, F.; Zhuang, C.; Li, C.; Yang, G.; Yao, H. Effect of Calcium Treatment on Inclusions in H08A Welding Rod Steel. Metals 2021, 11, 1227. https://doi.org/10.3390/ met11081227

Academic Editor: Andrii Kostryzhev

Received: 30 June 2021

Accepted: 28 July 2021

Published: 31 July 2021

Publisher's Note: MDPI stays neutral with regard to jurisdictional claims in published maps and institutional affiliations.

Copyright: (c) 2021 by the authors. Licensee MDPI, Basel, Switzerland. This article is an open access article distributed under the terms and conditions of the Creative Commons Attribution (CC BY) license (https:// creativecommons.org/licenses/by/ $4.0 /)$.
Abstract: The effect of calcium treatment on inclusions in H08A welding rod steel was studied by industrial experiment and using thermodynamics theory. The effects of inclusion composition, morphology, quantity, and size in H08A welding rod steel before and after calcium treatment were studied by metallographic microscope, scanning electron microscope (SEM), and energy dispersive spectrometer (EDS). Thermodynamic studies show that the addition of calcium can form various forms of $\mathrm{xCaO} \cdot \mathrm{yAl}_{2} \mathrm{O}_{3}$, under the condition that the composition of molten steel remains unchanged, the control of calcium content is the key to generate low melting point calcium-aluminate complex non-metallic inclusions and improve the quality of molten steel. The production practice in steel plant shows that for welding rod steels, the calcium content in a suitable range can meet the requirements of calcium treatment. Effective calcium treatment can not only transform the high melting point $\mathrm{Al}_{2} \mathrm{O}_{3}$ inclusions into the low melting point complex non-metallic inclusions between $3 \mathrm{CaO} \cdot \mathrm{Al}_{2} \mathrm{O}_{3}$ and $12 \mathrm{CaO} \cdot 7 \mathrm{Al}_{2} \mathrm{O}_{3}$, but also make the original shape-diversified inclusions into the spherical calciumaluminate complex non-metallic inclusions. Meanwhile, the total number of inclusions and large-scale inclusions in welding rod steel are reduced, and the inclusions tend to disperse in the steel, which is very conducive to the improvement of steel quality. The results show that the modification path of magnesium aluminate spinel in steel is as follows: $\mathrm{Al}_{2} \mathrm{O}_{3} \rightarrow \mathrm{MgO}-\mathrm{Al}_{2} \mathrm{O}_{3} \rightarrow \mathrm{MgO}-\mathrm{CaO}-\mathrm{Al}_{2} \mathrm{O}_{3}$. In addition, calcium treatment can modify $\mathrm{MgO}-\mathrm{Al}_{2} \mathrm{O}_{3}$ spinel in steel into liquid $\mathrm{MgO}-\mathrm{CaO}-\mathrm{Al}_{2} \mathrm{O}_{3}$ complex non-metallic inclusions with low melting point.

Keywords: H08A welding rod steel; inclusion; calcium treatment

\section{Introduction}

With the rapid development of global infrastructure, the demand for steel in various countries is increasing; welding rod steels are the most consumed steel in the welding material industry [1]. In order to keep up with the pace of continuous updating of steel technology, welding process and welding consumables will be required to have new development. H08A welding rod steel is a kind of low-carbon and low-silicon steel. In order to ensure the weldability of welding rod steels, the requirements of chemical composition of the steel are very strict in the production of welding rod steels, which is difficult to produce. The composition requirements are shown in Table 1 [2]. In Table 1, the national standard is the technical requirements that are uniform across the country, and internal control standard is the requirement for steel composition of the steel manufacturers participating in the experiment. In general, the internal control standard is more demanding than the national standard.

The type, quantity, size, morphology, and distribution of non-metallic inclusions in steel have great influence on the quality of metal products. The influence of inclusions on steel is mainly reflected in the corrosion resistance, toughness, plasticity, fatigue resistance, 
and so on [3-7]. For H08A welding rod steel, the type, quantity, and size of inclusions in the steel are important factors to determine whether cracks, folds, scabs, and other defects occur in the steel. Moreover, the inclusions in welding rod steels have an important influence on the microstructure and mechanical strength of the weld deposit during welding. Generally, inclusions have a negative effect on the reliability and safety of welding rod steels' structural materials [8-14]. At present, the research of welding rod steels mainly focuses on crack resistance, fatigue, microstructure, and mechanical properties [7]. Hertzberg et al. [15] and Anderson et al. [16] found that the inclusion with stress concentration in welding rod steels can cause fracture at high-stress position, and the inclusion plays a key role in the crack propagation of steel.

Table 1. Chemical composition of welding rod steels (wt $\%)$.

\begin{tabular}{cccccc}
\hline Composition of Molten Steel & S & $\mathbf{P}$ & Mn & Si & C \\
\hline National standard & $\leq 0.030$ & $\leq 0.030$ & $0.300-0.600$ & $\leq 0.030$ & $\leq 0.100$ \\
Internal control standard & $\leq 0.025$ & $\leq 0.025$ & $0.350-0.550$ & $\leq 0.030$ & $0.040-0.090$ \\
\hline
\end{tabular}

At present, the research on inclusions in steel mainly focuses on reoxidation, mould powder, refractory, and the removal and denaturation of inclusions in the smelting process $[17,18]$. With the idea of oxidation metallurgy put forward, metallurgists think that instead of spending at a high cost to improve the purity of steel, it is better to modify inclusions in the steel to make them harmless, or even to achieve a benefit. Therefore, the size refinement and dispersion distribution of inclusions have become a research focus. Aluminum is often used as a deoxidizer in steel smelting because of its strong deoxidation ability and low cost. However, aluminum deoxidation will produce large size and cluster alumina inclusions, which will not only cause nozzle clogging, but also affect the steel properties during steel processing [19]. Therefore, calcium treatment can transform alumina inclusions into calcium-aluminate complex non-metallic inclusions with low melting point, which is an effective method of avoiding nozzle clogging [20-32]. N. verma et al. [33] concluded that the inclusion size in steel was minimal after two minutes of calcium treatment and then increased gradually. Yuan Fangming et al. [34] found that when the calcium content was less than $10 \mathrm{ppm}$, the solid fraction of inclusions in steel was more than $60 \%$.

Therefore, this paper studies the main source, quantity, and size distribution of inclusions in H08A welding rod steel, and the evolution and deformation of inclusions in H08A welding rod steel before and after calcium treatment. The transformation of inclusions after calcium treatment was predicted by thermodynamic calculation. By deepening the understanding of inclusions in welding rod steels, the theoretical basis for the inclusion conditioning is provided, and the production quality of welding rod steels is improved.

\section{Experiment}

In this study, the factory experiment of H08A welding rod steel was carried out using "Hot metal and scrap $\rightarrow$ 40t electric furnace $\rightarrow$ ladle furnace refining (LF) $\rightarrow$ vacuum degassing (VD) $\rightarrow 150 \mathrm{~mm} \times 150 \mathrm{~mm}$ continuous casting (CC)" production route. The production process flow chart of H08A welding rod steel is shown in Figure 1.

Two heats of experimental steel were selected as the object of study (A furnace and B furnace). Each furnace steel was sampled in LF refining furnace and VD furnace at the end of the smelting. After sampling, the samples were quickly put into water for cooling. The smelting process parameters of the two heats of experimental steel are shown in Table 2.

The samples will be processed into a $10 \mathrm{~mm} \times 10 \mathrm{~mm} \times 10 \mathrm{~mm}$ cube, which will be coarsely ground, finely ground, and polished. The morphology and size of inclusions were observed by Zeiss-Ultra-55 (Zeiss, Oberkochen, German) field emission scanning electron microscope (SEM). The composition of the inclusion was determined by energy dispersive spectrometer (EDS) (Zeiss, Oberkochen, German). The C and S elements in steel samples were determined by carbon-sulphur detector (Yanrui Instrument Co., Ltd., Chongqing, China); $\mathrm{N}$ and $\mathrm{O}$ were determined by nitrogen-oxygen determinator (Yanrui 
Instrument Co., Ltd., Chongqing, China), and ICP-AES (Huapu General Technology Co., Ltd., Shenzhen, China) analysis method was used to detect the selected elements. The main components of different process stages in two furnace steels are shown in Table 3. The chemical composition of LF steel sample is before calcium treatment, and the chemical composition of VD steel sample is after calcium treatment.

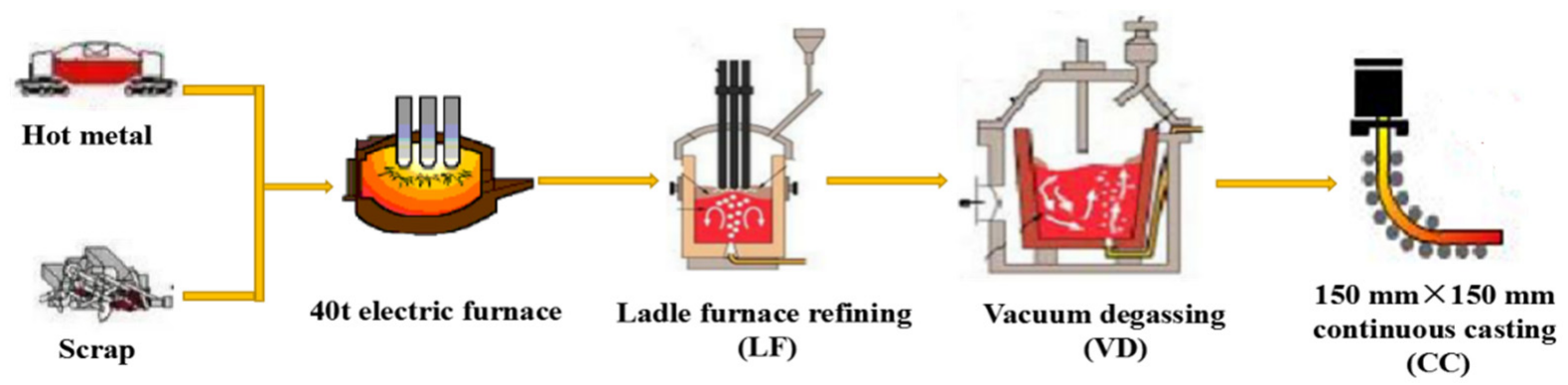

Figure 1. The production process of H08A welding rod steel.

Table 2. The operation parameters of calcium treatment in industrial production.

\begin{tabular}{cccccc}
\hline $\begin{array}{c}\text { Furnace } \\
\text { Times }\end{array}$ & $\begin{array}{c}\text { CaO content in } \\
\text { LF Refining } \\
\text { Furnace/kg }\end{array}$ & $\begin{array}{c}\text { LF Furnace } \\
\text { to Add Mn } \\
\text { Amount/kg }\end{array}$ & $\begin{array}{c}\text { LF Furnace to } \\
\text { Add Al } \\
\text { Amount/kg }\end{array}$ & $\begin{array}{c}\text { Ca addition at } \\
\text { VD Furnace }\end{array}$ & $\begin{array}{c}\text { VD Furnace } \\
\text { Soft Blow } \\
\text { Time/Min }\end{array}$ \\
\hline $\mathrm{A}$ & 550 & 20 & 60 & $100 \mathrm{~m}$ (Ca wire) & 15 \\
$\mathrm{~B}$ & 600 & 20 & 36 & $200 \mathrm{~m}$ (Fe-Ca wire) & 8 \\
\hline
\end{tabular}

Table 3. The chemical composition of steel samples in different working stations (wt $\%)$.

\begin{tabular}{|c|c|c|c|c|c|c|c|c|c|c|}
\hline \multirow{2}{*}{$\begin{array}{l}\text { Furnace } \\
\text { Number }\end{array}$} & \multirow{2}{*}{$\begin{array}{l}\text { Work } \\
\text { Station }\end{array}$} & \multicolumn{9}{|c|}{ Elements } \\
\hline & & $\mathrm{C}$ & Si & Mn & $\mathbf{P}$ & S & Als & Alt & $\mathrm{Ca}$ & [O] \\
\hline \multirow[b]{2}{*}{ A } & LF furnace & 0.0540 & 0.0130 & 0.4200 & 0.0050 & 0.0240 & 0.0140 & 0.0160 & 0.0002 & 0.0088 \\
\hline & VD furnace & 0.0640 & 0.0310 & 0.4600 & 0.0060 & 0.0030 & 0.0100 & 0.0110 & 0.0004 & 0.0067 \\
\hline & LF furnace & 0.0690 & 0.0160 & 0.4100 & 0.0040 & 0.0150 & 0.0130 & 0.0170 & 0.0006 & 0.0099 \\
\hline & VD furnace & 0.0860 & 0.0170 & 0.4300 & 0.0040 & 0.0050 & 0.0050 & 0.0050 & 0.0014 & 0.0068 \\
\hline
\end{tabular}

\section{Experiment Result}

\subsection{Typical Inclusions in Welding Rod Steel before and after Calcium Treatment}

Figure 2 shows the morphology and main composition of typical inclusions observed by scanning electron microscope in different positions of two steels. Figure 2a shows MnS inclusions in steel before calcium treatment, their shapes are mostly oval and a few are a long strip. There are two principal reasons for the introduction of MnS inclusions in H08A welding rod steel: one is that scrap steel is used as raw material in the production of H08A welding rod steel, which makes the elements in the smelting raw material become diversified-it is inevitable to introduce MnS inclusions in the steel; and the other is metal $\mathrm{Mn}$ added to LF refining furnace of the smelting process. Figure $2 \mathrm{~b}$ shows the single precipitated $\mathrm{Al}_{2} \mathrm{O}_{3}$ inclusions in steel, which are mostly elliptical. Figure $2 \mathrm{c}$ shows clusters of $\mathrm{MnS}-\mathrm{Al}_{2} \mathrm{O}_{3}$ complex non-metallic inclusions observed in the steel before calcium treatment.

According to Figure $2 \mathrm{~d}-\mathrm{f}$, it is obvious that there are $\mathrm{CaO}-\mathrm{Al}_{2} \mathrm{O}_{3}$ complex non-metallic inclusions, $\mathrm{MgO}-\mathrm{CaO}-\mathrm{Al}_{2} \mathrm{O}_{3}$ complex non-metallic inclusions, and $\mathrm{MgO}-\mathrm{Al}_{2} \mathrm{O}_{3}-\mathrm{MnS}$ complex non-metallic inclusions in H08A welding rod steel after calcium treatment. After calcium treatment, the inclusions in the steel are transformed to compounds of calcium, and by comparing the morphology pictures of inclusions, it can be found that the shape of inclusions tends to be more spherical after calcium treatment. 

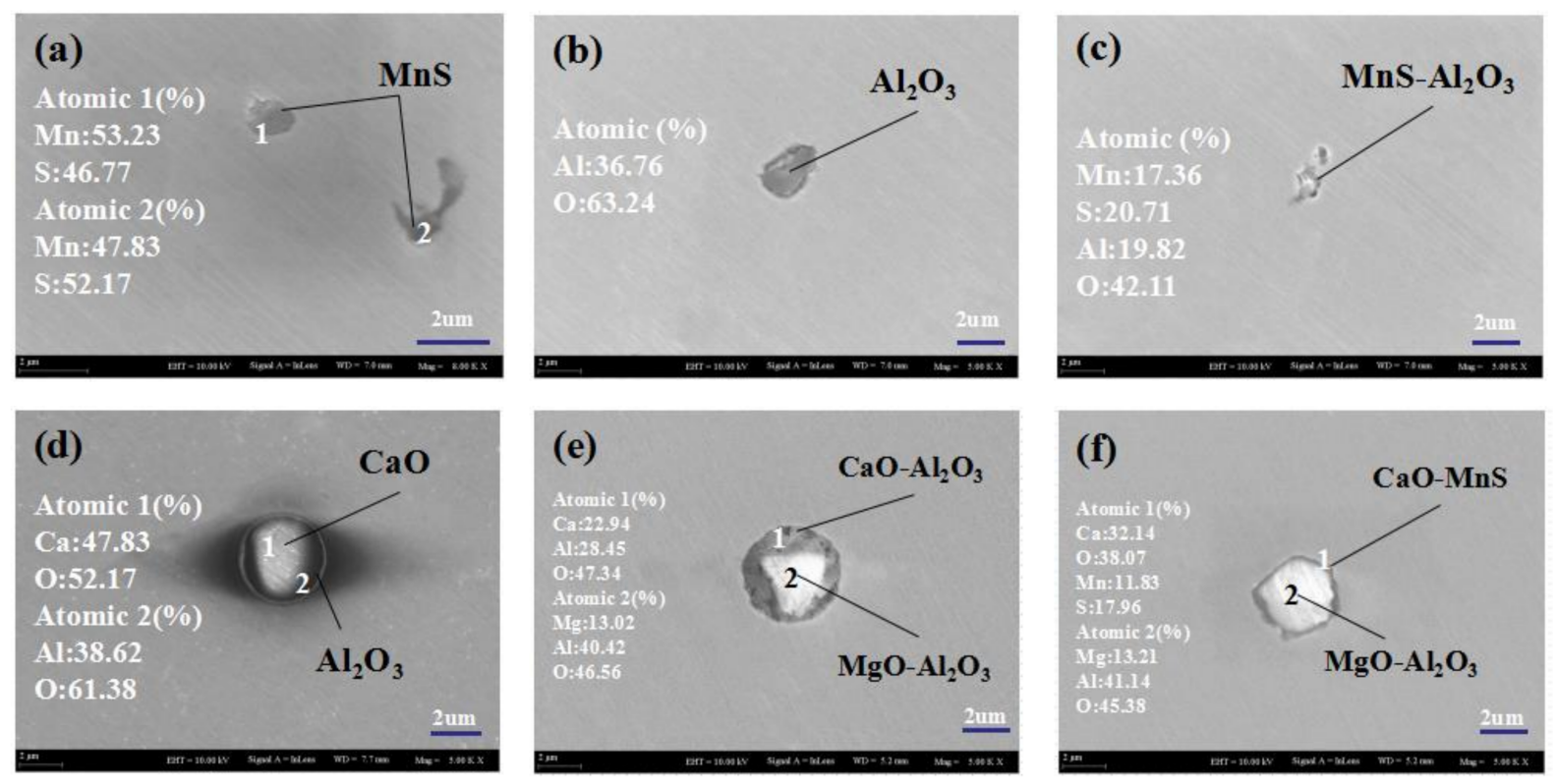

Figure 2. Typical non-metallic inclusions in steel at different stations $(\mathbf{a}-\mathbf{c})$ are pictures of non-metallic inclusions before calcium treatment; (d-f) are pictures of non-metallic inclusions after calcium treatment).

In order to show more intuitively the morphology and distribution of inclusions in calcium-treated steel, the scanning pictures of inclusions are shown in Figure 3. Figure 3a shows the $\mathrm{MgO}-\mathrm{Al}_{2} \mathrm{O}_{3}-\mathrm{CaO}-\mathrm{MnS}$ complex non-metallic inclusions in the steel. The inclusion is centered on $\mathrm{MgO}-\mathrm{Al}_{2} \mathrm{O}_{3}$, and $\mathrm{CaO}-\mathrm{MnS}$ precipitates around it; the inclusion in Figure $3 \mathrm{~b}$ is centered on $\mathrm{MgO}-\mathrm{Al}_{2} \mathrm{O}_{3}$, and $\mathrm{CaO}-\mathrm{Al}_{2} \mathrm{O}_{3}$ precipitates around it to form $\mathrm{MgO}-\mathrm{Al}_{2} \mathrm{O}_{3}-\mathrm{CaO}$ complex non-metallic inclusion.
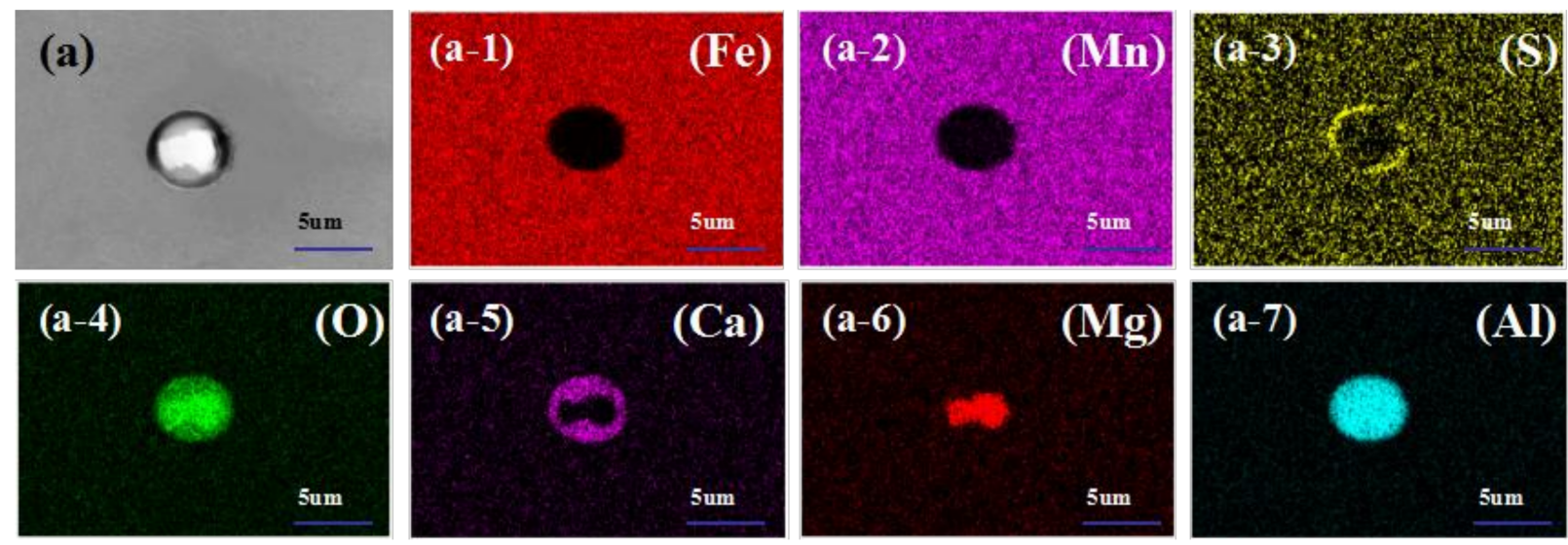

Figure 3. Cont. 

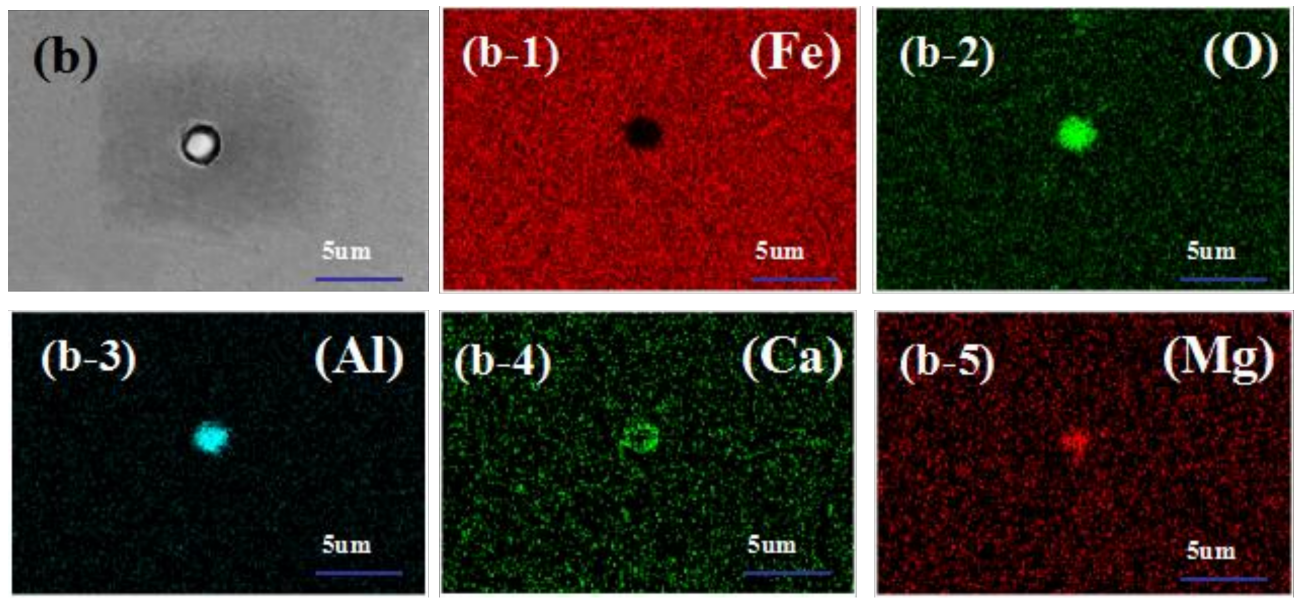

Figure 3. Scan of typical inclusions in H08A welding rod steel after calcium treatment ((a-1-a-7) are element distribution maps of (a); (b-1-b-5) are element distribution maps of (b)).

\subsection{Particle Size Distribution and Quantity Variation of Inclusions}

After coarse grinding, fine grinding, and polishing, the samples were made into metallographic samples, and the inclusions were analyzed by energy spectrum analysis under a scanning electron microscope. After having a certain understanding of the morphology of different inclusions, the morphology, size, and type of inclusions were observed under an optical microscope. The optical microscope, which has a magnification of 500 times, divides the size of inclusions into four grades, which are $\mathrm{m} \leq 1 \mu \mathrm{m}, 1 \mu \mathrm{m}<\mathrm{m} \leq 5 \mu \mathrm{m}$, $5 \mu \mathrm{m}<\mathrm{m} \leq 10 \mu \mathrm{m}$, and $\mathrm{m}>10 \mu \mathrm{m}$ (m represents the size of inclusions). The number of inclusions with different sizes in the steel at different working positions is obtained by using the method of lines, as shown in Figure 4.
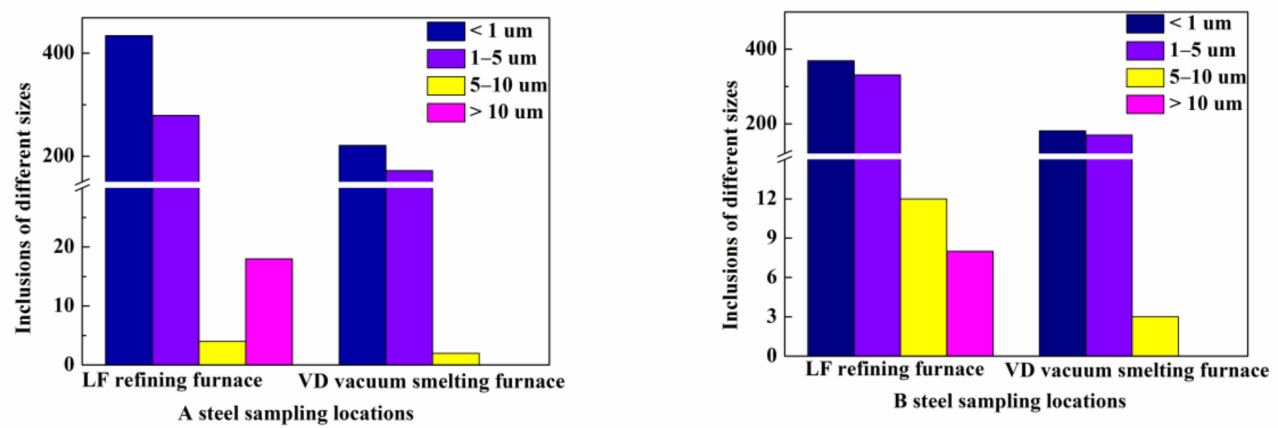

Figure 4. The number of inclusions of different sizes in different working steels.

It can be seen in Figure 4 that the number of inclusions of small size $(\mathrm{m} \leq 1 \mu \mathrm{m})$ accounts for the majority in each process, which is consistent with Ramirez's [35] conclusion that the average diameter of non-metallic inclusions in welding rod steels is between $0.3 \mu \mathrm{m}$ and $0.6 \mu \mathrm{m}$. The small inclusions are reduced from LF to VD, which indicates that soft blowing treatment of molten steel after feeding aluminum wire has a good effect on the removal of inclusions. For the inclusions with larger size $(\mathrm{m}>1 \mu \mathrm{m})$, there are more inclusions in the LF refining furnace, but the number decreases after the VD vacuum smelting furnace. One of the reasons is that most of the large inclusions in the initial liquid steel are $\mathrm{Al}_{2} \mathrm{O}_{3}$ inclusions, but after feeding calcium wire treatment, the calcium-aluminate complex non-metallic inclusions are formed and removed. Second, the soft blowing treatment of molten steel is very beneficial to the floating of large particle inclusions, so the number of inclusions has decreased; it can also be explained by Stokes's law that large inclusions can be separated faster and easier than small inclusions. 
In order to directly describe the distribution of inclusions, according to the data of the two-dimensional coordinates of inclusions on the surface of the samples and the area of each inclusion, the area percentage of inclusions in the steel matrix per unit area on the surface of the samples at different positions was calculated, as shown in Figure 5. Figure 5a,b shows the inclusion area density distribution before and after calcium treatment in A steel, respectively; and Figure $5 \mathrm{c}$, d shows inclusion area densities distribution before or after calcium treatments in B steel, respectively. It can be seen in Figure 5 that the distribution of inclusions in H08A welding rod steel without calcium treatment is obviously uneven; the surface density of inclusions per unit area of steel is relatively high, and there is a segregation area of inclusions, and the maximum area density of inclusions is $0.9650 \%$. The surface density of inclusions in the steel treated with calcium is less than $0.3550 \%$, and the distribution of calcium-aluminate complex non-metallic inclusions is more uniform than that of alumina inclusions.
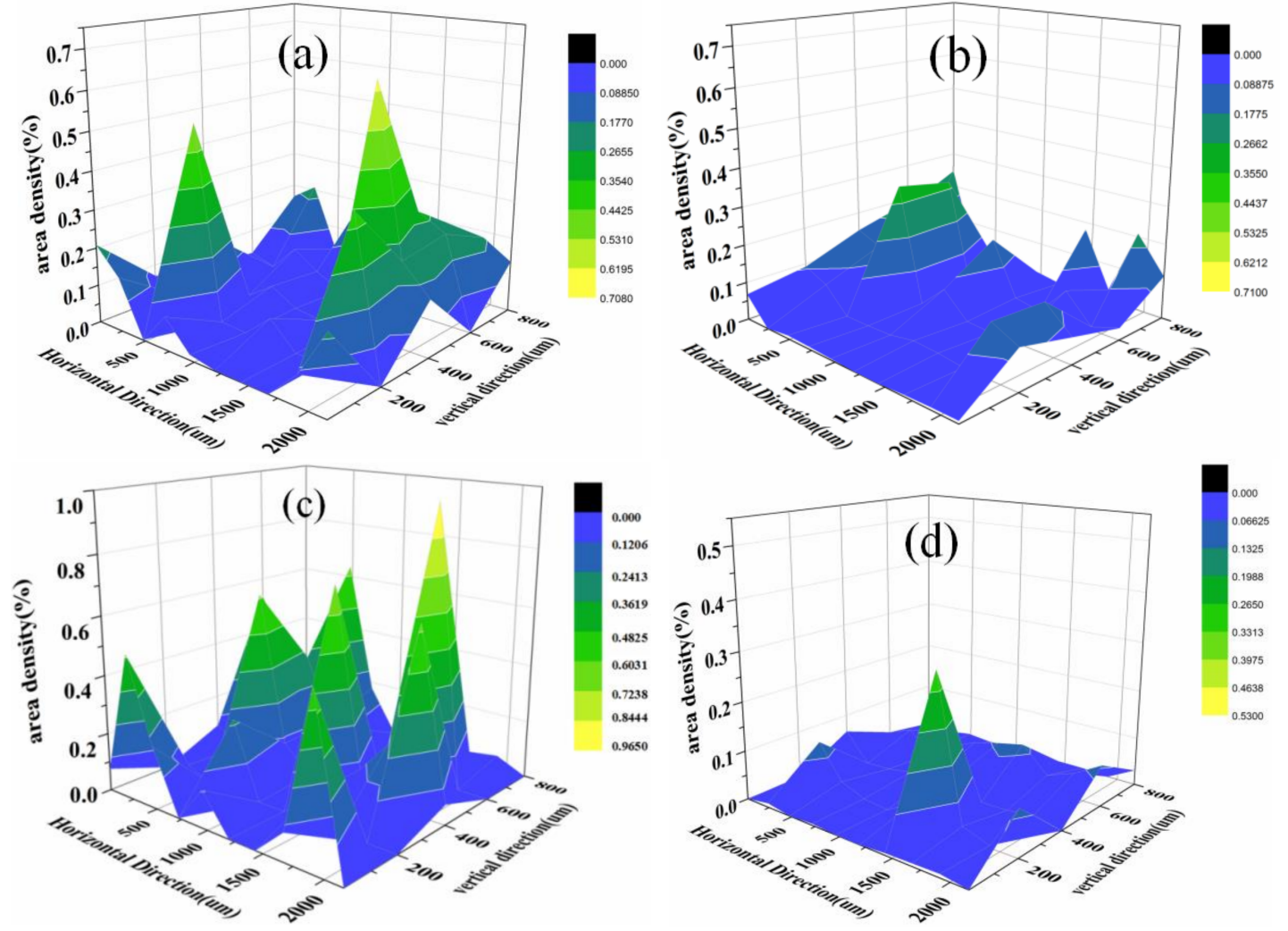

Figure 5. The variation of inclusion area density distribution in H08A welding rod steel treated with calcium: (a,b) for inclusion area density distribution before and after calcium treatment of steel A; and (c,d) for inclusion area density distribution before and after calcium treatment of steel B.

\subsection{Effect of Calcium Treatment on Composition of Magnesium Aluminate Spinel in Steel}

The composition of magnesium inclusions in steel samples from LF and VD furnaces (before and after calcium treatment) was analyzed by EDS. The percentages of $\mathrm{Mg}, \mathrm{Al}$, $\mathrm{Ca}$, and $\mathrm{O}$ elements of non-metallic inclusions in steel were obtained by energy dispersive spectrometer. These percentages were attributed to the mass percentages of $\mathrm{MgO}, \mathrm{Al}_{2} \mathrm{O}_{3}$, and $\mathrm{CaO}$ inclusions in the steel. Then the mass percentages of the three oxide inclusions are projected into the ternary phase diagram of the $\mathrm{MgO}-\mathrm{Al}_{2} \mathrm{O}_{3}-\mathrm{CaO}$ system. The results are shown in Figure 6. In Figure 6, the red curve region is the liquid region of the low melting point inclusion at a temperature of $1873 \mathrm{~K}$. 


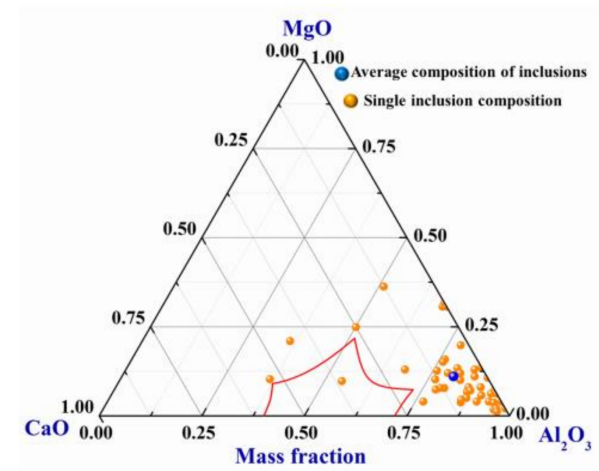

(a)

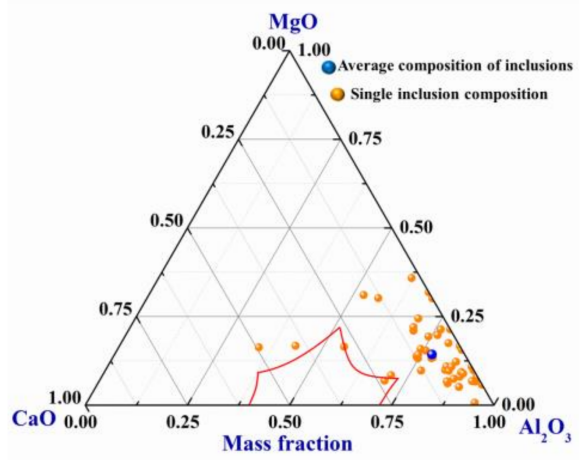

(c)

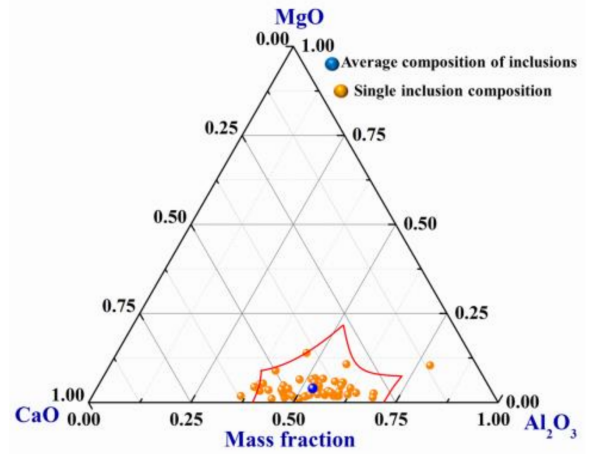

(b)

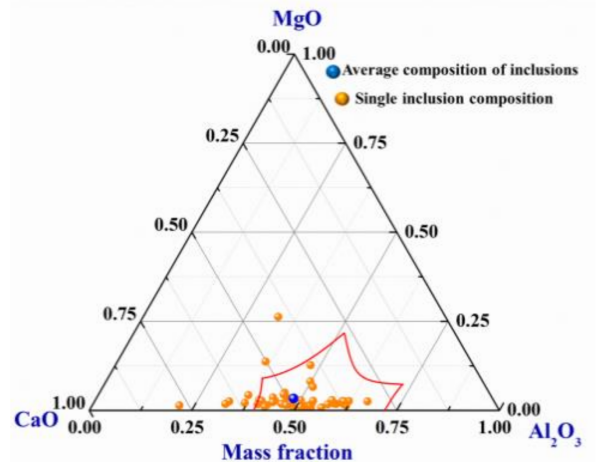

(d)

Figure 6. The change of inclusion composition in steel before and after calcium treatment: $(\mathbf{a}, \mathbf{b})$ are the changes of inclusions in steel A before and after calcium treatment; and $(\mathbf{c}, \mathbf{d})$ are the changes of inclusions in steel B before and after calcium treatment.

As can be seen in Figure 6, the $\mathrm{MgO}-\mathrm{Al}_{2} \mathrm{O}_{3}-\mathrm{CaO}$ complex non-metallic inclusions in the steel before calcium treatment are mainly concentrated in the $\mathrm{Al}_{2} \mathrm{O}_{3}$ corner of the ternary phase diagram. After calcium treatment, more and more $\mathrm{MgO}-\mathrm{Al}_{2} \mathrm{O}_{3}-\mathrm{CaO}$ complex non-metallic inclusions in the steel move away from the corner of $\mathrm{Al}_{2} \mathrm{O}_{3}$ and enrich to the liquid region. From the average composition of inclusions, it can be seen that the contents of $\mathrm{MgO}$ and $\mathrm{Al}_{2} \mathrm{O}_{3}$ in $\mathrm{MgO}-\mathrm{Al}_{2} \mathrm{O}_{3}-\mathrm{CaO}$ inclusions begin to decrease and the content of $\mathrm{CaO}$ increases after calcium treatment. It is shown that the $\mathrm{MgO}-\mathrm{Al}_{2} \mathrm{O}_{3}$ and $\mathrm{MgO}-\mathrm{Al}_{2} \mathrm{O}_{3}-\mathrm{CaO}$ complex non-metallic inclusions can be effectively modified into liquid inclusions by calcium treatment.

\section{Analysis and Discussion}

\subsection{Effect of Calcium Treatment on $\mathrm{Al}_{2} \mathrm{O}_{3}$ Non-Metallic Inclusions in Steel}

In the calcium treatment process, its main purpose is to change the high melting point $\mathrm{Al}_{2} \mathrm{O}_{3}$ inclusion (melting point $2054{ }^{\circ} \mathrm{C}$ ) into a composition close to $12 \mathrm{CaO} \cdot 7 \mathrm{Al}_{2} \mathrm{O}_{3}$ inclusion (melting point $1392^{\circ} \mathrm{C}$ ), so as to reduce the harmful effect of $\mathrm{Al}_{2} \mathrm{O}_{3}$ inclusion and improve the castability of molten steel. The binary system phase diagram of $\mathrm{Al}_{2} \mathrm{O}_{3}-\mathrm{CaO}$ is shown in Figure 7. In Figure 7, it can be seen that the composition of low melting point compound is between $\mathrm{C}_{3} \mathrm{~A}$ and $\mathrm{C}_{12} \mathrm{~A}_{7}$. However, improper calcium treatment process may lead to the formation of $\mathrm{CaO}, \mathrm{CaS}$ and high melting point calcium-aluminate complex non-metallic inclusions ( $\mathrm{CA}, \mathrm{CA}_{6}$, and $\mathrm{CA}_{2}$ ). These inclusions are not easy to float and remove in molten steel, which greatly increases the probability of blocking the nozzle. Some researchers have pointed out that improper calcium treatment is more likely to cause clogging than no calcium treatment $[36,37]$. 


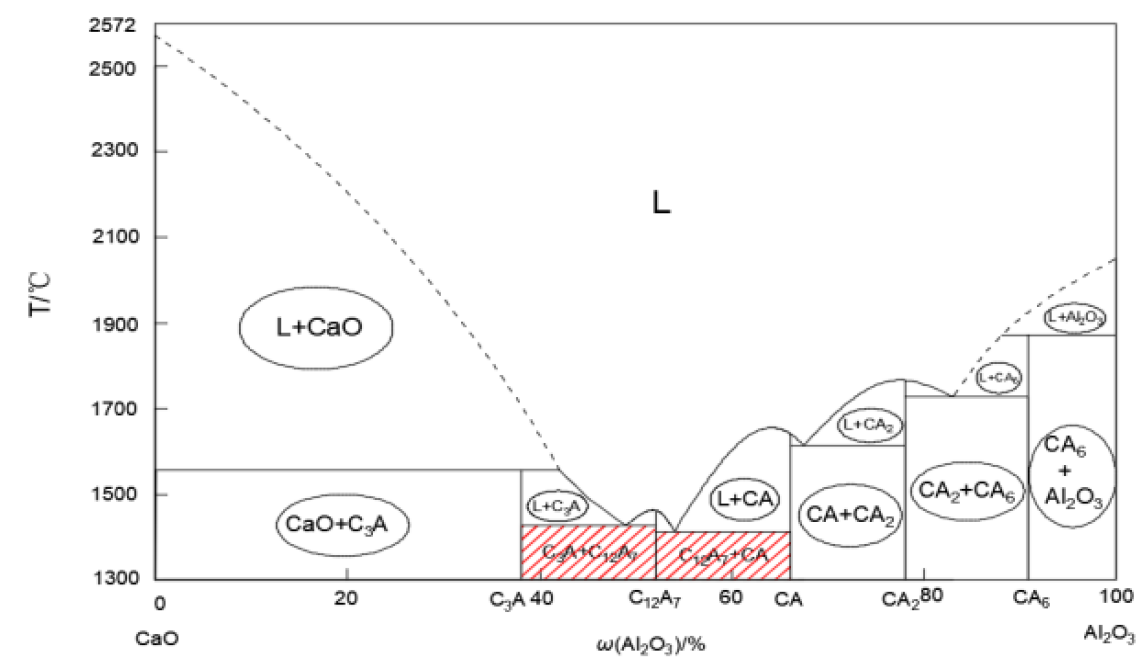

Figure 7. A phase diagram of the $\mathrm{Al}_{2} \mathrm{O}_{3}-\mathrm{CaO}$ binary system.

The Wagner model $[24,38]$ was used to calculate the activity of elements in liquid steel by Equation (1), using the mass fraction of elements in liquid steel (Table 3) and the interaction coefficient of elements in liquid steel (Table 4) [32,39,40].

$$
\begin{aligned}
\lg f_{i} & =\sum\left(e_{i}^{j} \cdot[j \%]\right) \\
\lg a_{[i]} & =\lg f_{i}+\lg [\% i]
\end{aligned}
$$

Table 4. The interaction coefficients between elements.

\begin{tabular}{cccccccc}
\hline & \multicolumn{7}{c}{$j$} \\
\cline { 2 - 8 } & $\mathbf{C}$ & $\mathbf{S i}$ & $\mathbf{M n}$ & $\mathbf{S}$ & $\mathbf{A l}$ & $\mathbf{O}$ & $\mathbf{C a}$ \\
\hline $\mathrm{Al}$ & 0.091 & 0.057 & 0.0065 & 0.035 & -0.043 & -1.98 & -0.047 \\
$\mathrm{Ca}$ & -0.34 & -0.097 & -0.0156 & -28 & -0.072 & -310 & -0.002 \\
\hline
\end{tabular}

$\mathrm{a}_{[i]}$-Activity of element $i$.

$f_{i}$-Activity coefficient of element $i$.

$e_{i}^{j}$-Coefficient of primary interaction of element $j$ with element $i$.

$\mathrm{Al}_{2} \mathrm{O}_{3}$ inclusions in steel may form under the action of $\mathrm{Ca}$ in liquid steel. There are five kinds of calcium-aluminate complex non-metallic inclusions, and the order of their growth and transformation is as follows: $\mathrm{Al}_{2} \mathrm{O}_{3} \rightarrow \mathrm{CaO} \cdot 6 \mathrm{Al}_{2} \mathrm{O}_{3}\left(\mathrm{CA}_{6}\right) \rightarrow \mathrm{CaO} \cdot 2 \mathrm{Al}_{2} \mathrm{O}_{3}\left(\mathrm{CA}_{2}\right)$ $\rightarrow \mathrm{CaO} \cdot \mathrm{Al}_{2} \mathrm{O}_{3}(\mathrm{CA}) \rightarrow 12 \mathrm{CaO} \cdot 7 \mathrm{Al}_{2} \mathrm{O}_{3}\left(\mathrm{C}_{12} \mathrm{~A}_{7}\right) \rightarrow 3 \mathrm{CaO} \cdot \mathrm{Al}_{2} \mathrm{O}_{3}\left(\mathrm{C}_{3} \mathrm{~A}\right)$. According to the sequence of calcium-aluminate complex non-metallic isnclusions transformation, the thermodynamic calculation model of the precipitation of different composition of calciumaluminate complex non-metallic inclusions can be obtained by thermodynamic calculation. The calculation process is shown in Equations (3)-(8) in Table 5 [36].

Table 5. The equilibrium constants of compound formation.

\begin{tabular}{ccc}
\hline Reaction Equation & $\Delta G^{\theta}$ & Serial Number \\
\hline $2[\mathrm{Al}]+3[\mathrm{O}]=\mathrm{Al}_{2} \mathrm{O}_{3}$ & $\Delta G^{\theta}=-1202000+386.3 T$ & $(3)$ \\
$3[\mathrm{Ca}]+19 \mathrm{Al}_{2} \mathrm{O}_{3}=3\left(\mathrm{CaO} \cdot 6 \mathrm{Al}_{2} \mathrm{O}_{3}\right)+2[\mathrm{Al}]$ & $\Delta G^{\theta}=-786553-59.9 T$ & $(4)$ \\
$12[\mathrm{Ca}]+7\left(\mathrm{CaO} \cdot 6 \mathrm{Al}_{2} \mathrm{O}_{3}\right)_{(\mathrm{s})}=19\left(\mathrm{CaO} \cdot 2 \mathrm{Al}_{2} \mathrm{O}_{3}\right)_{(\mathrm{s})}+8[\mathrm{Al}]$ & $\Delta G^{\theta}=-3134242-19.58 T$ & $(5)$ \\
$3[\mathrm{Ca}]+4\left(\mathrm{CaO} \cdot 2 \mathrm{Al}_{2} \mathrm{O}_{3}\right)_{(\mathrm{s})}=7\left(\mathrm{CaO} \cdot \mathrm{Al}_{2} \mathrm{O}_{3}\right)_{(\mathrm{s})}+2[\mathrm{Al}]$ & $\Delta G^{\theta}=-802303+30.7 T$ & $(6)$ \\
$15[\mathrm{Ca}]+33\left(\mathrm{CaO} \cdot \mathrm{Al}_{2} \mathrm{O}_{3}\right)_{(\mathrm{s})}=4\left(12 \mathrm{CaO} \cdot 7 \mathrm{Al}_{2} \mathrm{O}_{3}\right)_{(\mathrm{s})}+10[\mathrm{Al}]$ & $\Delta G^{\theta}=-56555-1609.66 T$ & $(7)$ \\
$9[\mathrm{Ca}]+2\left(12 \mathrm{CaO} \cdot 7 \mathrm{Al}_{2} \mathrm{O}_{3}\right)_{(\mathrm{s})}=11\left(3 \mathrm{CaO} \cdot \mathrm{Al}_{2} \mathrm{O}_{3}\right)_{(\mathrm{s})}+14[\mathrm{Al}]$ & $\Delta G^{\theta}=-28685511+1108.65 T$ & $(8)$ \\
\hline
\end{tabular}


The activity coefficients and activities of calcium and aluminum in furnace $\mathrm{A}$ and furnace $B$ can be calculated by using Equations (1) and (2) combined with the data in mboxtabreftabref:metals-1300502-t004. The results are listed in Table 6.

Table 6. The activity coefficient and activity of $\mathrm{Ca}$ and $\mathrm{Al}$ in calcium treated steel.

\begin{tabular}{lcccc}
\hline Furnace Times & $f_{A l}$ & $a_{A l}$ & $f_{C a}$ & $a_{C a}$ \\
\hline A Furnace-VD & 0.9883 & 0.0208 & 0.0064 & $2.572 \times 10^{-6}$ \\
B Furnace-VD & 0.9930 & 0.0099 & 0.0052 & $7.2660 \times 10^{-6}$ \\
\hline
\end{tabular}

The relation between the equilibrium constant $k$ of the reaction and the Gibbs free energy $\Delta G^{\theta}$ is expressed by the following formula:

$$
\ln k=-\frac{\Delta G^{\theta}}{R T}
$$

where $T$ is temperature, and unit $\mathrm{k} ; R=8.314 \mathrm{~Pa} \times \mathrm{m}^{3} \times(\mathrm{mol} \times \mathrm{K})^{-1}$.

According to the thermodynamic data of chemical reaction Equations (3)-(9), the classical thermodynamic data calculation method is used. According to the abscissa of aluminum activity and the ordinate of calcium activity, the equilibrium relations of calciumaluminate complex non-metallic inclusions are obtained, as shown in Figure 8.

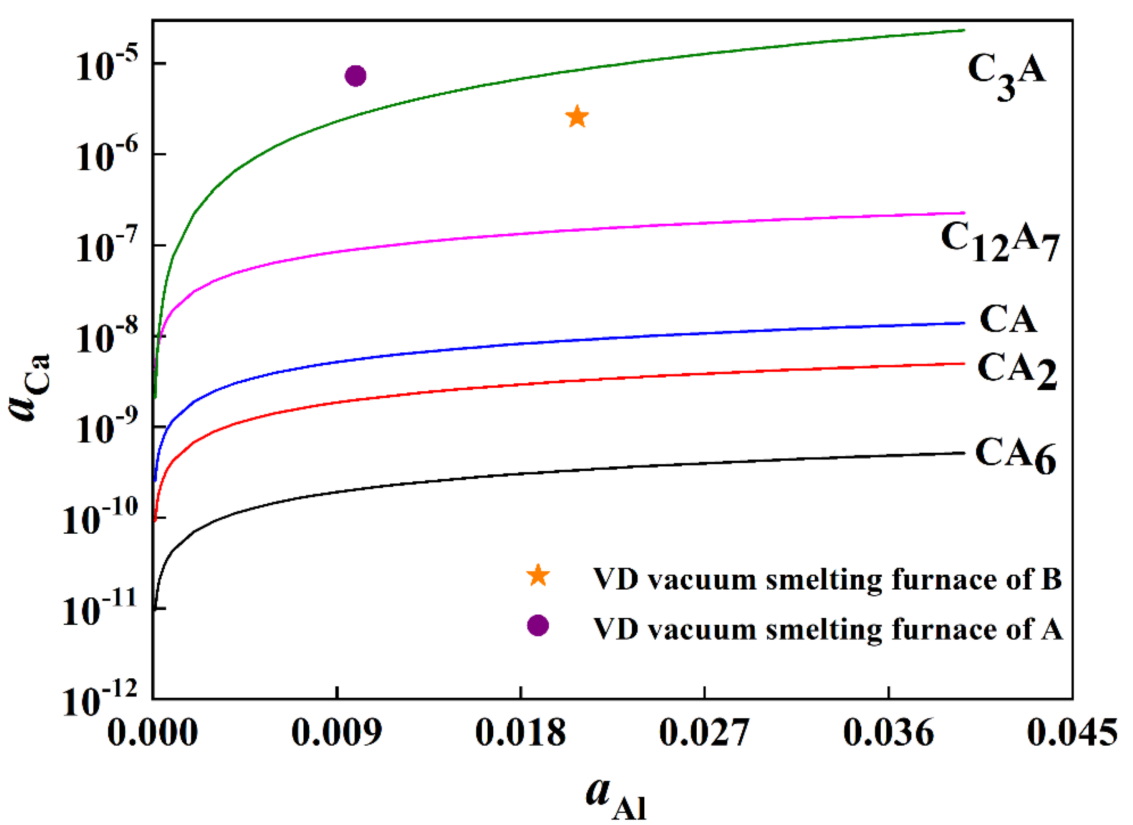

Figure 8. Generating balance diagrams for different calcium-aluminate complex non-metallic inclusions.

Based on the phase diagram of $\mathrm{CaO}-\mathrm{Al}_{2} \mathrm{O}_{3}$ system, it is shown that low melting point calcium-aluminate complex non-metallic inclusions will be formed when inclusions are formed between $C_{3} A$ and $C_{12} A_{7}$. As can be seen in Figure 8 , when the aluminum activity in steel is constant, the calcium activity only needs to be within an appropriate range to achieve the desired effect of calcium treatment. According to the activity values of calcium and aluminum in A and B steel VD furnaces in Table 6, two points in Figure 8 are obtained. The results of thermodynamic calculation show that the inclusion types after calcium treatment are $\mathrm{C}_{12} \mathrm{~A}_{7}$ and $\mathrm{C}_{3} \mathrm{~A}$. This is consistent with the experimental results, indicating that calcium treatment is effective. 


\subsection{Effect of Calcium Treatment on Magnesium Aluminate Spinel in Steel}

In the smelting process of molten steel, because the lining is smelting at high temperature all year round, it is inevitable that magnesium aluminate spinel inclusions will be introduced because of shedding. Aluminum in molten steel can also react with magnesium oxides in slag, resulting in magnesium aluminate spinel. This is also the reason why some $\mathrm{MgO}-\mathrm{Al}_{2} \mathrm{O}_{3}$ is observed in the steel samples collected in the LF furnace (before calcium treatment). The reaction formula can be expressed by Equations (10) and (11). In LF stage, metal aluminum was used for strong deoxidation and high basicity slag was used. The $\mathrm{Al}$ in molten steel could reduce $\mathrm{MgO}$ in slag or lining. The reduced $\mathrm{Mg}$ goes into the molten steel and reacts with the $\mathrm{Al}_{2} \mathrm{O}_{3}$ inclusions in the steel to form the magnesium aluminate spinel.

$$
\begin{gathered}
2[\mathrm{Al}]+3(\mathrm{MgO})=3[\mathrm{Mg}]+\left(\mathrm{Al}_{2} \mathrm{O}_{3}\right) \\
3[\mathrm{Mg}]+4\left(\mathrm{Al}_{2} \mathrm{O}_{3}\right)=3\left(\mathrm{MgO} \times \mathrm{Al}_{2} \mathrm{O}_{3}\right)+2[\mathrm{Al}]
\end{gathered}
$$

In the steel samples collected in VD stage (after calcium treatment), some $\mathrm{CaO}-\mathrm{MgO}-$ $\mathrm{Al}_{2} \mathrm{O}_{3}$ complex inclusions can also be observed. This is mainly the reaction between [Ca] and $\mathrm{MgO}-\mathrm{Al}_{2} \mathrm{O}_{3}$ inclusions in molten steel after calcium treatment to form the $\mathrm{CaO}-\mathrm{MgO}-$ $\mathrm{Al}_{2} \mathrm{O}_{3}$ complex non-metallic inclusions. The reaction thereof is shown in Equation (12).

$$
x[\mathrm{Ca}]+\left(\mathrm{MgO} \cdot \mathrm{Al}_{2} \mathrm{O}_{3}\right)=x[\mathrm{Mg}]+\left[x \mathrm{CaO} \cdot(1-x) \mathrm{MgO} \cdot \mathrm{Al}_{2} \mathrm{O}_{3}\right]
$$

After calcium treatment, most of the $\mathrm{MgO}-\mathrm{Al}_{2} \mathrm{O}_{3}$ complex non-metallic inclusions in molten steel are transformed into $\mathrm{CaO}-\mathrm{MgO}-\mathrm{Al}_{2} \mathrm{O}_{3}$ complex non-metallic inclusions with a relatively low melting point. This can be confirmed by the experimental results in Figure 5. This kind of inclusion is a liquid inclusion in the smelting process, and it is easy to be removed by collision and accumulation in the process of rising. The probability of nozzle clogging in the smelting process is reduced. As can be seen in Figures $2 \mathrm{e}$ and $3 \mathrm{~b}$, the core of $\mathrm{CaO}-\mathrm{MgO}-\mathrm{Al}_{2} \mathrm{O}_{3}$ complex non-metallic inclusions is mainly composed of $\mathrm{MgO}$ and $\mathrm{Al}_{2} \mathrm{O}_{3}$, and almost no $\mathrm{CaO}$ is found in the center. In contrast, $\mathrm{CaO}-\mathrm{MgO}-\mathrm{Al}_{2} \mathrm{O}_{3}$ complex non-metallic inclusions are mainly composed of $\mathrm{CaO}$ and $\mathrm{Al}_{2} \mathrm{O}_{3}$. It is shown that the reaction between $\mathrm{Ca}$ and $\mathrm{MgO}-\mathrm{Al}_{2} \mathrm{O}_{3}$ spinel in calcium treated steel is an outward inward process. The reaction mechanism of $\mathrm{Ca}$ and $\mathrm{MgO}-\mathrm{Al}_{2} \mathrm{O}_{3}$ spinel in calcium treated steel can be inferred from the experimental results, as shown in Figure 9.

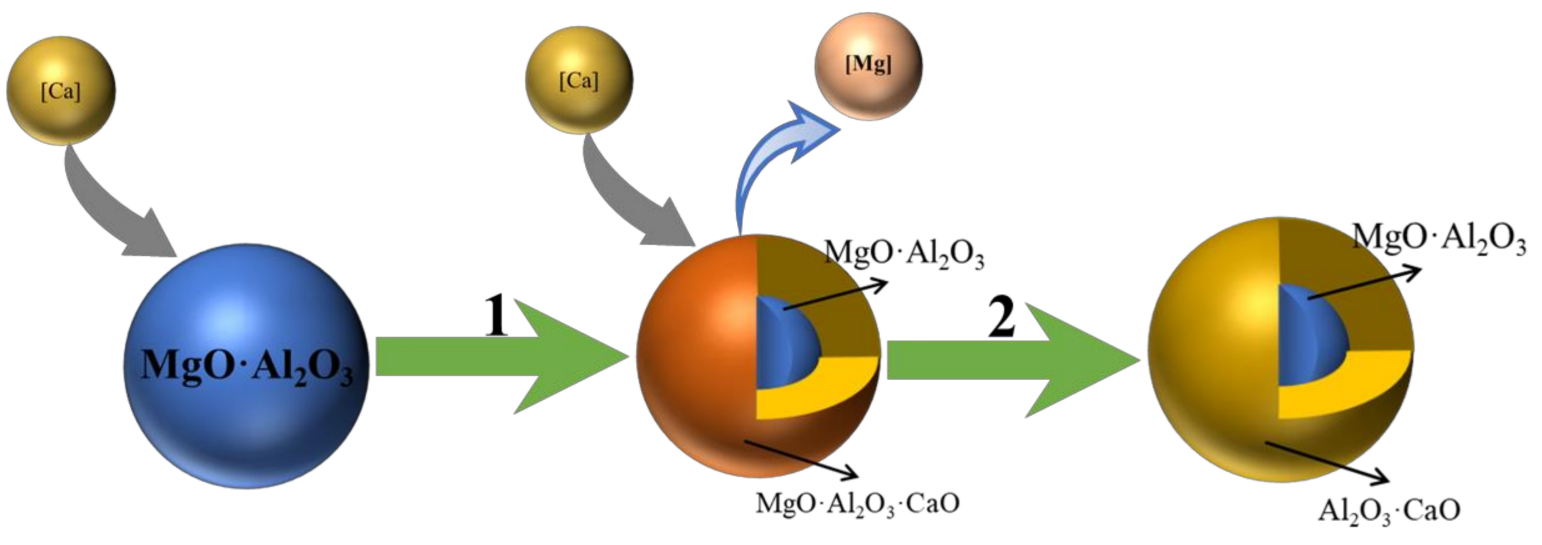

Figure 9. The modification of $\mathrm{MgO}-\mathrm{Al}_{2} \mathrm{O}_{3}$ complex non-metallic inclusions in steel by calcium treatment.

In Figure 9, each type of inclusion is assumed to be spherical. Ca in the molten steel is transferred to the surface of $\mathrm{MgO}-\mathrm{Al}_{2} \mathrm{O}_{3}$ spinel and reacts with it as shown in Process 1 in Figure 9. The reaction process is expressed by formula (12). In this process, Ca reacts with $\mathrm{MgO}-\mathrm{Al}_{2} \mathrm{O}_{3}$ spinel surface to form a complex inclusion outer layer of $\mathrm{CaO}-\mathrm{MgO}-\mathrm{Al}_{2} \mathrm{O}_{3}$. $\mathrm{Mg}$ from the reaction is transferred to the molten steel. 
$\mathrm{Ca}$ in the molten steel continues to react with an outer layer of $\mathrm{CaO}-\mathrm{MgO}-\mathrm{Al}_{2} \mathrm{O}_{3}$, until all $\mathrm{CaO}-\mathrm{MgO}-\mathrm{Al}_{2} \mathrm{O}_{3}$ inclusions in the outer layer are converted to $\mathrm{CaO}-\mathrm{Al}_{2} \mathrm{O}_{3}$ inclusion, that is, process 2 in Figure 9. At this time, the inclusions in the outer layer will be transformed in the order of $\mathrm{CA}_{6} \rightarrow \mathrm{CA}_{2} \rightarrow \mathrm{CA} \rightarrow \mathrm{C}_{12} \mathrm{~A}_{7} \rightarrow \mathrm{C}_{3} \mathrm{~A}$. This is similar to the case of calcium treatment for $\mathrm{Al}_{2} \mathrm{O}_{3}$ inclusions described previously.

During the reaction process of $\mathrm{CaO}-\mathrm{MgO}-\mathrm{Al}_{2} \mathrm{O}_{3}$ outer layer, the content of $\mathrm{Ca}$ in the outer layer will increase continuously, which will diffuse into $\mathrm{CaO}-\mathrm{MgO}-\mathrm{Al}_{2} \mathrm{O}_{3}$ inner layer. Furthermore, $\mathrm{MgO}-\mathrm{Al}_{2} \mathrm{O}_{3}$ spinel in $\mathrm{CaO}-\mathrm{MgO}-\mathrm{Al}_{2} \mathrm{O}_{3}$ continues to react with $\mathrm{Ca}$ to obtain the effect of layer-by-layer modification.

\section{Conclusions}

By adding metallic calcium to the H08A welding rod steel, it was found that MnS, $\mathrm{Al}_{2} \mathrm{O}_{3}$, and $\mathrm{MnS}-\mathrm{Al}_{2} \mathrm{O}_{3}$ were the main inclusions in $\mathrm{H} 08 \mathrm{~A}$ welding rod steel before calcium treatment. After calcium treatment, the inclusions in the steel begin to transform into $\mathrm{CaO}$ $\mathrm{Al}_{2} \mathrm{O}_{3}$ complex non-metallic inclusions, $\mathrm{MgO}-\mathrm{CaO}-\mathrm{Al}_{2} \mathrm{O}_{3}$ complex non-metallic inclusions, and $\mathrm{MgO}-\mathrm{Al}_{2} \mathrm{O}_{3}-\mathrm{MnS}$ complex non-metallic inclusions, and the inclusions morphology presents a spherical shape.

After calcium treatment, the number of inclusions in H08A welding rod steel decreased, and large inclusions in steel also showed a decreasing trend. Through the statistics of the surface density of inclusions in H08A welding rod, it is found that the distribution of inclusions in the steel after calcium treatment is more uniform, achieving fine dispersion of inclusions in the steel.

Different forms of calcium-aluminate will be formed under different calcium treatments with different calcium contents under the condition of certain composition in molten steel. It is verified by the production practice of the steel plant that the inclusion composition of $\mathrm{Al}_{2} \mathrm{O}_{3}$ with high melting point can be changed between $\mathrm{C}_{3} \mathrm{~A}$ and $\mathrm{C}_{12} \mathrm{~A}_{7}$ with low melting point by proper calcium content in the thermodynamics of calcium treatment. The experimental results are in agreement with the expected thermodynamic calculation results, achieving good results after calcium treatment.

Magnesium aluminate spinel in steel can be modified into liquid $\mathrm{MgO}-\mathrm{CaO}-\mathrm{Al}_{2} \mathrm{O}_{3}$ complex non-metallic inclusions with low melting point by calcium treatment. The reaction between $\mathrm{Ca}$ and $\mathrm{MgO}-\mathrm{Al}_{2} \mathrm{O}_{3}$ spinel in molten steel is an outward-inward, layer-by-layer reaction process. The process of formation and modification of $\mathrm{MgO}-\mathrm{Al}_{2} \mathrm{O}_{3}$ spinel in steel is as follows: $\mathrm{Al}_{2} \mathrm{O}_{3} \rightarrow \mathrm{MgO}-\mathrm{Al}_{2} \mathrm{O}_{3} \rightarrow \mathrm{MgO}-\mathrm{CaO}-\mathrm{Al}_{2} \mathrm{O}_{3}$.

Author Contributions: Conceptualization, C.Z. and F.L.; methodology, F.L. and C.Z.; software, F.L., G.Y. and H.Y.; validation, C.Z. and F.L.; formal analysis, C.L., G.Y. and H.Y.; investigation, C.L. and C.Z.; resources, C.Z.; data curation, F.L. and C.Z.; writing-original draft preparation, F.L. and C.Z.; writing-review and editing, F.L. and C.Z.; visualization, F.L.; supervision, C.Z.; project administration, C.Z. and C.L.; funding acquisition, C.Z. All authors have read and agreed to the published version of the manuscript.

Funding: This research was funded by National Natural Science Foundation of China, grant number 51704083 and 51864013, Guizhou Science and Technology Plan Project ([2017] 5788, [2018] 1026, [2019] 1115, and [2019] 2163), Education Department Foundation of Guizhou Province (No. [2017] 118), Guizhou Science Cooperation platform talents [2018] 5781 subsidy, and Research Foundation for Talents of Guizhou University (No. 201628).

Institutional Review Board Statement: Not applicable.

Data Availability Statement: The data used to support the findings of this study are available from the corresponding authors upon reasonable request.

Conflicts of Interest: The authors declare no conflict of interest. 


\section{References}

1. Zhang, T.; Li, Z.; Young, F.; Kim, H.J.; Li, H.; Jing, H.; Tillmann, W. Global Progress on Welding Consumables for HSLA Steel. ISIJ Int. 2014, 54, 1472-1484. [CrossRef]

2. Solid Wire Electrodes, Tubular Cored Electrodes and Electrode/Flux Combinations for Submerged Arc Welding of Non Alloy and Fine Grain Steels (ISO 14171:2016); Standards Press of China: Beijing, China, 2016.

3. Tanaka, K.; Akiniwa, Y. Fatigue Fract. Fatigue crack propagation behavior derived from S-N data in very high cycle regime. Fatigue Fract. Eng. Mater. Struct. 2002, 25, 775-784.

4. Akiniwa, Y.; Miyamoto, N.; Tsuru, H. Notch effect on fatigue strength reduction of bearing steel in the very high cycle regime. Int. J. Fatigue 2006, 28, 1555-1565. [CrossRef]

5. Shiozaw, K.; Hasegawa, T.; Kashiwagi, Y.; Lu, L. Very high cycle fatigue properties of bearing steel under axial loading condition. Int. J. Fatigue 2009, 31, 880-888. [CrossRef]

6. Shiozawa, K.; Murai, M.; Shimatani, Y.; Yoshimoto, T. Transition of fatigue failure mode of Ni-Cr-Mo low-alloy steel in very high cycle regime. Int. J. Fatigue 2010, 32, 541-550. [CrossRef]

7. Li, W.; Sakai, T.; Li, Q.; Lu, L.T.; Wang, P. Reliability evaluation on very high cycle fatigue property of GCr15 bearing steel. Int. J. Fatigue 2010, 32, 1096-1107. [CrossRef]

8. Li, X.; Zhang, J.; Shen, S.; Wang, Y.; Song, X. Effect of tempering temperature and inclusions on hydrogen-assisted fracture behaviors of a low alloy steel. Mater. Sci. Eng. A 2016, 682, 359-369. [CrossRef]

9. Sun, Q.; Di, H.S.; Li, J.C.; Wu, B.Q.; Misra, D.K.R. A comparative study of the microstructure and properties of $800 \mathrm{MPa}$ microalloyed C-Mn steel welded joints by laser and gas metal arc welding. Mater. Sci. Eng. A 2016, 669, 150-158. [CrossRef]

10. Filho, W.W.B.; Carvalho, A.L.M.; Bowen, P. Micromechanisms of cleavage fracture initiation from inclusions in ferritic welds: Part I. Quantification of local fracture behaviour observed in notched testpieces. Mater. Sci. Eng. A 2007, 460, 436-452. [CrossRef]

11. Wang, G.Z.; Liu, Y.G.; Chen, J.H. Investigation of cleavage fracture initiation in notched specimens of a C-Mn steel with carbides and inclusions. Structural Materials. Mater. Sci. Eng. A 2004, 369, 181-191. [CrossRef]

12. Hsieh, K.C.; Babu, S.S.; Vitek, J.M.; David, S.A. Calculation of inclusion formation in low-alloy-steel welds. Mater. Sci. Eng. A 1996, 215, 84-91. [CrossRef]

13. Osio, A.S.; Liu, S.; Olson, D.L. The effect of solidification on the formation and growth of inclusions in low carbon steel welds. Mater. Sci. Eng. A 1996, 221, 122-133. [CrossRef]

14. Jing, H.; Huo, L.; Zhang, Y.J. Simulation of Stable Crack Growth for Welded Joints Including Strength Mismatching. Mater. Sci. Technol. 1999, 15, 567-570.

15. Hertzberg, R.W.J. Deformation and fracture mechanics of engineering materials. Eng. Mater. Technol. 1976, 99, 1. [CrossRef]

16. Anderson, T.L. Fracture Mechanics: Fundamentals and Applications; CRC Press: Boca Raton, FL, USA, 1991.

17. Holappa, L.; Hämäläinen, M.; Liukkonen, M.; Lind, M. Thermodynamic examination of inclusion modification and precipitation from calcium treatment to solidified steel. Ironmak. Steelmak. 2020, 30, 111-115. [CrossRef]

18. Han, P.W.; Chu, S.J.; Ping, M.E.; Lin, Y.F. Oxide Inclusions in Ferromanganese and Its Influence on the Quality of Clean Steels. J. Iron Steel Res. Int. 2014, 21, 23-27. [CrossRef]

19. Papamantellos, D.; Angelopoulos, G.; Dourdounis, E.; Gotsis, V.; Catana, C.; Mavromatis, K.; Weckes, J. Inclusion floating process for super clean steels. Environ. Sci. Eur. 2003, 20597, 1-59.

20. Wang, Y.; Sun, X.; Zhang, L.; Ren, Y. Effect of calcium treatment on inclusions in Si-Mn-killed 304 stainless steels. J. Mater. Res. Technol. 2020, 9, 11351-11360. [CrossRef]

21. Ren, Q.; Yang, W.; Cheng, L.; Hu, Z.; Zhang, L. Effect of calcium treatment on magnetic properties of non-oriented electrical steels. J. Magn. Magn. Mater. 2020, 494, 165803. [CrossRef]

22. Tanaka, Y.; Pahlevani, F.; Kitamura, S.; Privat, K.; Sahajwalla, V. Behaviour of Sulphide and Non-alumina-Based Oxide Inclusions in Ca-Treated High-Carbon Steel. Metall. Mater. Trans B 2020, 51, 1384-1394. [CrossRef]

23. Ren, Q.; Yang, W.; Cheng, L.; Zhang, L.; Conejo, A.N. Process. Formation and Deformation Mechanism of $\mathrm{Al}_{2} \mathrm{O}_{3}-\mathrm{CaS}$ Inclusions in Ca-Treated Non-Oriented Electrical Steels. metallurgy and materials processing science. Metall. Mater. Trans. 2020, 51, $200-212$. [CrossRef]

24. Pan, C.; Hu, X.; Zheng, J.; Lin, P.; Chou, K. Effect of calcium content on inclusions during the ladle furnace refining process of AISI 321 stainless steel. Int. J. Miner. Metall. Mater. 2020, 27, 1499-1507. [CrossRef]

25. Zheng, H.; Guo, S.; Qiao, M.; Qin, L.; Zou, X.; Ren, Z. Study on the modification of inclusions by Ca treatment in GCr18Mo bearing steel. Adv. Manuf. 2019, 7, 438-447. [CrossRef]

26. Abraham, S.; Bodnar, R.; Raines, J.; Wang, Y.; Zhang, L. Inclusion engineering and metallurgy of calcium treatment. J. Iron Steel Res. Int. 2018, 25, 133-145. [CrossRef]

27. Guo, Y.; He, S.; Chen, G.; Wang, Q. Process. Thermodynamics of Complex Sulfide Inclusion Formation in Ca-Treated Al-Killed Structural Steel. metallurgy and materials processing science. Metall. Mater. Trans B 2016, 47, 2549-2557. [CrossRef]

28. Yang, G.; Wang, X.; Huang, F.; Yang, D.; Wei, P.; Hao, X. Influence of Calcium Addition on Inclusions in LCAK Steel with Ultralow Sulfur Content. Process metallurgy and materials processing science. Metall. Mater. Trans B I 2015, 46, 145-154. [CrossRef]

29. Yang, D.; Wang, X.; Yang, G.; Wei, P.; He, J. Inclusion Evolution and Estimation during Secondary Refining in Calcium Treated Aluminum Killed Steels. Steel Res. Int. 2014, 85, 1517-1524. [CrossRef] 
30. Ren, Y.; Zhang, L.; Li, S. Transient Evolution of Inclusions during Calcium Modification in Linepipe Steels. ISIJ Int. 2014, 54, 2772-2779. [CrossRef]

31. Yang, S.; Li, J.; Wang, Z.; Li, J.; Lin, L. Modification of $\mathrm{MgO} \cdot \mathrm{Al}_{2} \mathrm{O}_{3}$ spinel inclusions in Al-killed steel by Ca-treatment. Int. J. Miner. Metall. Mater. 2011, 18, 18-23. [CrossRef]

32. Liu, J.; Wu, H.; Bao, Y.; Wang, M. Inclusion variations and calcium treatment optimization in pipeline steel production. Int. J. Miner. Metall. Mater. 2011, 18, 527-534. [CrossRef]

33. Verma, N.; Pistorius, P.C.; Fruehan, R.J.; Potter, M.; Lind, M.; Story, S. Process. Transient Inclusion Evolution During Modification of Alumina Inclusions by Calcium in Liquid Steel: Part II. Results and Discussion. metallurgy and materials processing science. Metall. Mater. Trans B 2011, 42,711-719. [CrossRef]

34. Fangming, Y.A.; Xinhua., W.A.; Xuefu. Y., B. Influence of calcium content on solid ratio of inclusions in Ca-treated liquid steel. Int. J. Miner. Metall. Mater. 2006, 13, 486-489.

35. Ramirez, J.E. Characterization of High-Strength Steel Weld Metals: Chemical Composition, Microstructure, and Nonmetallic Inclusions. Weld J. 2008, 87, 65-75.

36. Choudhary, S.K.; Ghosh, A. Thermodynamic Evaluation of Formation of Oxide-Sulfide Duplex Inclusions in Steel. ISIJ Int. 2008, 48, 1552-1559. [CrossRef]

37. Yang, X.; Wang, M.; Wang, J.; Wang, W. Effect of Calcium Treatment on Non-Metallic Inclusions in Ultra-Low Oxygen Steel Refined by High Basicity High $\mathrm{Al}_{2} \mathrm{O}_{3}$ Slag. J. Iron Steel Res. Int. 2011, 18, 7. [CrossRef]

38. Paek, M.K.; Jang, J.M.; Jiang, M.; Pak, J.J. Thermodynamics of AlN Formation in High Manganese-Aluminum Alloyed Liquid Steels. ISIJ Int. 2013, 53, 973-978. [CrossRef]

39. Itoh, H.; Hino, M.; Ban-Ya, S. Thermodynamics on the formation of spinel nonmetallic inclusion in liquid steel. Metall. Mater. Trans. B 1997, 28, 953-956. [CrossRef]

40. Zheng, W.; Wu, Z.; Li, G.; Zhang, Z.; Zhu, C. Effect of Al Content on the Characteristics of Inclusions in Al-Ti Complex Deoxidized Steel with Calcium Treatment. ISIJ Int. 2014, 54, 1755-1764. [CrossRef] 